\title{
Public health nursing: regulation and public health policies
}

\author{
A enfermagem de saúde pública: regulação e políticas públicas de saúde \\ La enfermería de salud pública: regulación y las políticas públicas de salud
}

\section{Carmen Maria dos Santos Lopes Monteiro da Cunha' ORCID: 0000-0001-5418-8377 \\ Maria Adriana Pereira Henriques' ORCID: 0000-0003-0288-6653 \\ Andreia Cátia Jorge Silva Costa ORCID: 0000-0002-2727-4402}

'Universidade de Lisboa, Escola Superior de Enfermagem. Lisboa, Portugal.

How to cite this article: Cunha C, Henriques A, Costa A. Public health nursing: regulation and public health policies. Rev Bras Enferm. 2020;73(6):e20190550. doi: http://dx.doi.org/10.1590/0034-7167-2019-0550

\section{Corresponding author:}

Carmen Cunha

E-mail: carmencunha@campus.esel.pt

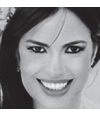

EDITOR IN CHIEF: Antonio José de Almeida Filho ASSOCIATE EDITOR: Fátima Helena Espírito Santo

Submission: 07-22-2019

Approval: 03-26-2020

\section{ABSTRACT}

Objective: To analyze regulation and public policies related to nursing and the specialist nurse in community and public health nursing. Methods: Analysis of the legal and normative framework of community and public health nursing in Portugal, as well as current public health policies, regarding the competences and intervention of this nurse, articulated with the attributions of the Public Health Unit. Results: The intervention of this nurse deserves a broad reflection, in the sense of maximizing the activities of community and public health, essential for the implementation of public policies and obtaining health gains. Final considerations: This nurse has competences foreseen in the regulations and standards for public health interventions, in line with the attributions of the Public Health Unit, of the National Health Service, in which specialties are identified for their performance in the current structure.

Descriptors: Nursing; Public Health Nursing; Regulation; Public Health; Public Health Policies.

\section{RESUMO}

Objetivo: Analisar a regulação e as políticas públicas relativas à enfermagem e ao enfermeiro especialista em enfermagem de saúde comunitária e de saúde pública. Método: Análise do enquadramento legal e normativo da enfermagem de saúde comunitária e pública em Portugal, bem como das atuais políticas públicas de saúde, no que diz respeito às competências e intervenção desse enfermeiro, articuladas com as atribuições da Unidade de Saúde Pública. Resultados: A intervenção desse enfermeiro merece uma reflexão alargada, no sentido da maximização das atividades de âmbito comunitário e de saúde pública, fundamental para a implementação das políticas públicas e obtenção de ganhos em saúde. Considerações finais: Esse enfermeiro tem previstas competências nos regulamentos e normas para intervenções de saúde pública, em linha com as atribuições da Unidade de Saúde Pública, do Serviço Nacional de Saúde, em que se identificam especialidades para o seu desempenho na atual estrutura.

Descritores: Enfermagem; Enfermagem de Saúde Pública; Regulação; Saúde Pública; Políticas Públicas de Saúde.

\section{RESUMEN}

Objetivo: Analizar la regulación y las políticas públicas relacionadas con la enfermería y el enfermero especializado en salud comunitaria y enfermería en salud pública. Métodos: Análisis del marco legal y normativo de la enfermería de salud pública y comunitaria en Portugal, así como las políticas actuales de salud pública, con respecto a las habilidades e intervención de este enfermero, articuladas con los deberes de la Unidad de Salud Pública. Resultados: La intervención de este enfermero merece una amplia reflexión, en el sentido de maximizar las actividades de salud comunitaria y pública, fundamentales para la implementación de políticas públicas y la obtención de beneficios para la salud. Consideraciones finales: Este enfermero tiene las competencias previstas en los reglamentos y normas para las intervenciones de salud pública, de acuerdo con las obligaciones de la Unidad de Salud Pública, del Servicio Nacional de Salud, en el que se identifican especialidades por su desempeño en la estructura actual. Descriptores: Enfermería; Enfermería de Salud Pública; Regulación; Salud Pública; Políticas de Salud Pública. 


\section{INTRODUCTION}

What is public health and why is it relevant to nursing is one of the questions presented by the authors ${ }^{(1)}$, who suggest that the nurse is ideally placed to support people in making healthy choices, given the nature of the therapeutic relationship that develops between them and the patient / client / family; and why such a relationship is established when people have to face their vulnerabilities to illness and other threats to their health ${ }^{(1)}$.

The reflection dedicated to the competences of the specialist nurse in community and public health requires analysis of public policies, presented as sets of provisions, measures and methods that concretize the political orientation of the State and determine actions and activities of public interest ${ }^{(2)}$.

Public health policies, in turn, are inserted in the social action of the State, in the sense of improving the health conditions of the population and the natural, social and work environments, in the sense of organizing governmental public functions, for the promotion, protection and recovery of the health of individuals and communities ${ }^{(2)}$. According to the Commission for Public Health Reform, in Portugal, it is about protecting and promoting the health of the populations as well as preventing disease, in a joint effort by the whole society to not only improve the level of health and well-being, but also to reduce inequalities, especially social ones in health, as these are the central objectives of Public Health ${ }^{(3)}$.

We therefore propose to characterize, albeit briefly, the relevance of nursing and the specialist nurse in community and public health nursing, in Portugal, in the sphere of public health, scrutinizing their current issues, regulation and policies in which it is inserted, to contextualize the respective interventions.

Taking into account the recent positions taken, in the scope of the discussion of the Public Health Law Proposal(4), of the representative body of the nurses 'class, the Order of Nurses (ON), and of professional organizations, such as the Nurses' Unions, it is understood that perspectives remain, that have not yet been agreed, regarding the competences and interventions of nursing professionals, in the area of public health.

Thus, in the Parliamentary Committee on Public Health, the ON referred, in particular: to the composition of the directions and coordination of public health services, which must include nurses; collaborative practices and allocation of responsibilities.

For the Portuguese Nurses Union, in the same Commission, it is important to estimate the necessary resources and budgets, so a compensatory system based on a prevention regime for all professionals involved and indicative ratios for them are recommended.

The intervention of the specialist nurse in community and public health nursing takes place through the evaluation of the health status of a community, its training, program coordination and epidemiological surveillance, as provided for in Regulation / ON n 428/2018 ${ }^{(5)}$.

Returning to the proposal of the Public Health Law, already mentioned, which aims to regulate all this area of intervention and interest of the State, it is important to mention that it foresees as actors:

public health services include specialist doctors in public health, specialist nurses in public health or community nursing, environmental health technicians, sanitary engineers and other senior health technicians, senior technician nutritionists, psychologists, oral hygienists and other diagnostic technicians and therapeutic and technical assistants, and can also integrate other professionals deemed necessary, according to their differentiation ${ }^{(4)}(\mathrm{p} .9)$.

Even in an international perspective, in this era of increasing restrictions on public resources, which affect health services and also manifest themselves in other realities, it is important to know what, in practice, adds the intervention of the specialist nurse in community health nursing and public health ${ }^{(6)}$.

\section{OBJECTIVE}

Analyze regulation and public policies related to nursing and the specialist nurse in community and public health nursing.

\section{METHODS}

This reflective study, of a theoretical nature, addresses the rules and a regulation, in the Portuguese context, related to public health, and is inserted in the investigation of the Competences and Interventions of the Specialist nurse in community and public health nursing, focusing on this nurse. Not being a study of systematic literature review, we proceeded to the analysis of documents contained in national databases and websites of governmental organizations, about the theme.

The presentation of reflections, to be aligned, will give a guiding axis on the theme that can allow interpretation and / or reflection of the analyzed documents. The interpretation / reflection carried out will enable the understanding of the theme directed to the Portuguese and Brazilian reality. As there was no direct research interaction, the need to submit this reflection to an Ethics Committee was excluded.

\section{RESULTS}

Currently in Portugal, public health is different from that of the modernist or sanitary era, since both problems and knowledge are different. Advances in genetics, molecular biology, new technologies and powerful telematics and information systems, such as the internet, are important contributions to postpone the end of life and increase its quality throughout its cycle, constituting new and important challenges for public health and health system responses ${ }^{(7)}$.

Under Article 64 of the Constitution of the Portuguese Republic ${ }^{(8)}$, health is a right and an assignment for all, and the State guarantees its universality and generality:

"1. Everyone has the right to health protection and the assignment to defend and promote it." This right is realized, "a) Through a national service of universal and general health and, taking into account the economic and social conditions of citizens, tendency free of charge;" and "b) For the creation of conditions (...) that guarantee, namely, the protection of children, youth and old age, and (...) for the development of the people's health education and healthy living practices".

These fundamental rights and guarantees are embodied in other rules, such as the Basic Health Law ${ }^{(9)}$, and influence 
the whole architecture of health care in Portugal, centered on people, groups and communities, as well as the professionals who provide them.

According to Base 28 of the referred law, "Health professionals have the right and the assignment inserted in professional careers, to exercise their activity in accordance with the legislation and deontological rules, and must respect the rights of the person they care for, but may exercise the objection of conscience under the law. (...)", and it is up to the Ministry of Health to organize a national register of health professionals. This determination does not exclude the mandatory registration in a professional association under public law, as is the case with nurses, whose Order was created by Decree-Law No. 104/98, of 21 April, which is responsible for professional regulation and discipline of the nurse's practice.

Thus, by the Regulation of Professional Practice of Nurses, ON distinguishes two nursing professionals, the general care nurse and the specialist nurse. The first is the one qualified with the Nursing course legally recognized and with the professional title of ON; and the second is the one qualified with a specialization course in Nursing, or with a course of higher studies specialized in Nursing, as well as the respective professional title recognized by ON.

In this reflection, it is the specialist nurse in community and public health nursing who is at the center of attention, for his interventions with populations, communities and groups. Recently, he was the object of special attention in Regulation / ON n०428/2018 (5), which presents:

The profile of specific competences of the Specialist nurse in Community Nursing that integrates, together with the profile of the common competences of the specialist nurse defined in a specific regulation, the set of specialized clinical competences and implemented according to the target and context of intervention, in the area of community and public health nursing (p. 19354).

For the College of Community Nursing Specialty, of the ON, the concepts of public health and community health are different. Public health refers to "the state of health of a certain group of people and of government activities and conditions (guaranteed by the state), with a view to promoting, protecting or preserving health." Community health "refers to the health status of a community, as a defined group of people, and its activities and conditions (public or private) to promote, protect or preserve its health."

\section{Public Health Policies}

The Portuguese government highlights as Public Health Policies ${ }^{(10)}$, first of all, promoting public health, in order to obtain health gains, through intervention in the respective determinants and articulation with social action and education.

And, particularly, regarding public health, the following measures stand out:

Creation of a National Health Education, Literacy and SelfCare Program, preparing and supporting informal home care providers, (...) Implementing Local Health Plans in compliance with the National Health Plan (NHP); Strengthen epidemiological surveillance, health promotion, primary prevention and secondary prevention; Revitalize the Communicable Disease Control Program to face the new epidemics, (...)Promote measures to prevent smoking (extending access to smoking cessation consultations), healthy eating (collective eating in schools and work environments) and preventing alcohol consumption and other addictive products; (...)

These are the current public policy options in the area of health, and deserve to be the focus of attention, especially since, in April 2018, the World Health Organization (WHO) presented its Health System Review, Portugal, in which points out, as major challenges for our health system, issues such as: dealing with family deprivation, unemployment and child poverty; increasingly older population linked to unemployment and youth emigration; the majority of users of the National Health Service (NHS) have more than one chronic disease, with an increase in the prevalence of multimorbidity; and the need for a special focus on actions that increase the expectation of a healthy life, especially among older women. These challenges should be observed in the Brazilian context as well.

Thus, there is a wide field of action for health professionals, including the specialist nurse in community and public health nursing, to implement policies, intentions and recommendations. They, in their interventions in community and public health, are an actor of these policies and an active and fundamental "entrepreneur" in favor of the improvement and gains in health of the populations.

\section{The Community Health and Public Health Nurse and Public Health Unit's Attributions}

According to Decree-Law no 81/2009, of April 2, "in each Health Center Group (HCG) or, with the necessary adaptations, in each local health unit, there is a Public Health Unit (PHU), which has organizational and technical autonomy" (p. 2060). In these units, the specialist nurse in community and public health nursing, integrated in multidisciplinary teams, is responsible for collaborating in the elaboration of information, public health plans, epidemiological surveillance, monitoring of the population's health status, diagnosis, elaboration of the local health plan; and propose interventions to reduce problems, or reinforce health gains ${ }^{(11)}$. In other words, this is the field in which the specialist nurse in community and public health nursing implements his competences, through his interventions.

$\mathrm{PHU}$ is the name given to one of the functional units foreseen for HCGs, which is responsible, in the geodemographic area of HCG in which it is integrated, for the exercise of a set of attributions, provided for in Decree-Law No. 28/2008, of 22 February. The PHU team consists of public health doctors, specialist nurse in community health and public health nurses, environmental health technicians and oral hygienists, and also, permanently or in temporary collaboration, other professionals needed in the area of public health.

Combining the competences of the specialist nurse in community and public health nursing, provided for in Regulation / ON No. 428/2018(5), with PHU's attributions, provided for in the aforementioned Decree-Law, it must be concluded that this professional has competences for most of PHU's attributions, as a result of the joint reading of the two realities: 1 . Establishes, based on the Health Planning methodology, the assessment of the health status 
of a community - which is linked to the attribution of elaborating information and plans in public health domains; 2 . Performs and cooperates in epidemiological surveillance of geodemographic scope - which is related to the task of carrying out epidemiological surveillance; 3 . Contributes to the qualification process of groups and communities and integrates the coordination of Health Programs at the community level and in the achievement of the objectives of the National Health Plan - which appears to be linked to the attribution of managing intervention programs within the scope of prevention, promoting and protecting the health of the general population or specific groups.

We found that the only PHU attribution for which there is no correspondence in the competences of the specialist nurse in community and public health nursing, is to collaborate, according to the respective legislation, in the exercise of the health authority functions. This is understood because, under the same law, the functions of health authority are performed by public health doctors.

Hence, it can be seen that the specialist nurse in community and public health nursing is at the center of all these competences, from prevention to promotion and training. The allocation of responsibilities and activities among professionals as well as their interaction can be adapted, creating new management strategies and models with these nurses, that can equate national programs, from management to execution ${ }^{(12)}$.

In the light of Brazilian public policies, nursing must be understood as part of a social structure, and the performance of the nurse's role enables changes in health policies and acts in reducing social inequalities, among other actions ${ }^{(13)}$. Among the many competences of the public health nurse, they are also planning and executing actions, supervising direct assistance to populations or managing health services ${ }^{(14)}$. Of the reforms that are being considered, this reflection can contribute to identify points of leverage for the development of health policies, in which the specialist nurse in community and public health nursing can actively participate.

\section{DISCUSSION}

PHUs, defined by the primary health care reform in 2008, have their attributions operationalized through a contract promoted by the Ministry of Health, through its central services, such as the Central Administration of the Health System (CAHS), which publishes the respective referential and matrix ${ }^{(15)}$. Thus, in 2018, it did so by presenting a contractual framework based on the competence matrix, ensuring compliance with PHU's "Basic Service Portfolio", namely as a local health observatory; governance for health and well-being; epidemiological surveillance; environmental health; integrated management and participation in the execution of health programs and projects; health authority; continuing education and pre-graduate and post-graduate training for different professional groups; and health research.

The internal contracting of 2018 consisted of a negotiation with the PHUs of its action plan, to define its activity in the area of influence of HCG, based on a multidimensional matrix, which breaks down the references into areas, sub-areas and dimensions and which specifies the work to be carried out, as illustrated in Figure 1:

$\begin{array}{lll}\begin{array}{l}\text { Area of } \\ \text { Assistance } \\ \text { Performance }\end{array} & \begin{array}{l}\text { Sub-areas } \\ \text { Observation of } \\ \text { the State of Health } \\ \text { and Welfare of the } \\ \text { Population }\end{array} & \begin{array}{l}\text { Dimensions } \\ \text { Health Situation Diagnosis } \\ \text { Epidemiological } \\ \text { Surveillance and } \\ \text { Public Health }\end{array} \\ \begin{array}{ll}\text { Emergency Response } \\ \text { Determinants }\end{array} & \begin{array}{l}\text { Characterization of Community } \\ \text { Support Structures }\end{array} \\ & \text { Health Risk Cards } \\ & \text { Contingency Plans } \\ & \text { Epidemiological Research }\end{array}$

Figure 1 - Multidimensional matrix for the Public Health Unit

The dimensions of the multidimensional matrix are linked to specific execution indicators, which point to the respective evaluation. This contract has an evaluation stage, which will allow to assess the unit's capacity to perform.

In the team of professionals at this $\mathrm{PHU}$, the specialist nurse in community and public health nursing has the competences to be part of and undertake most activities of the dimensions described. The Health System Review, Portugal (WHO) reinforces that nurses are the group with the largest number of health workers. However, their number is low when compared to international standards, even though only a quarter of these professionals work in the community. A change will be necessary for chronic diseases to be effectively monitored in their real life contexts.

It is also important to note that the same report points out as challenges, in the scope of human resources, the need for decentralization using only the implementation of policies and mentions, in particular, that health is still very centered on doctors, despite significant changes in capacities of other actors. The implementation of public policies must be complemented with the development of human resources and not remain, as up to now, in strategic plans. It is also worth mentioning the discussion about the expansion of the role of nurses in Portugal ${ }^{(16)}$.

In this sense, the defense of the dissemination of governance models by nurses is considered relevant, even for the recognition of these professionals, in their ability to coordinate and implement programs at national and local levels, especially related to children and vaccination. Thus, one will seek to obtain health gains and place Portugal among the European countries with the best results in this field ${ }^{(12)}$, as well as encouraging multi-localized studies that highlight the best interventions of the specialist nurse in community and public health nursing ${ }^{(6)}$.

\section{Study limitations}

To be just a reflection and not to have been made a systematization from the historical point of view.

\section{Contributions to Nursing, Health or Public Policy}

Despite the limitation, we consider that this reflection is a contribution to the area of public health, in the sense that the intervention of the specialist nurse in community and public health nursing deserves a broad reflection, viewing to maximize community activities, fundamental for the implementation of 
public policies and obtaining health gains. This work highlights, in view of the legal and normative documents, the relevance attributed to nursing performance in public health and can be an embryonic element in the development of the competences of this nurse and public health policies, since nurses are the largest group of professionals in health.

\section{FINAL CONSIDERATIONS}

Understanding what public health is and giving visibility to specialist nurses in community and public health nursing, who intervene in it, has been the focus of our special attention. From the questions posed by the Portuguese Order of Nurses and the Portuguese Nurses'Union, regarding the professional's situation, to the rules and regulations, as well as public health policies, it is understood that the focus is always on promotion, prevention, protection and recovery health of individuals and communities.

This reflective study addresses nursing, the competences and interventions of the specialist nurse in community and public health nursing. The authors supported themselves in the research in national databases and websites of governmental and non-governmental organizations. The fundamental rights and guarantees, provided for in the Portuguese Constitution, also in relation to health, are materialized in norms, such as the Base Health Law, which defines, in Portugal, the architecture of the National Health Service.

Recently, WHO pointed out challenges to the Portuguese health system, in which the specialist nurse in community and public health nursing is identified as a fundamental professional, being able to eventually redefine functions to ensure greater effectiveness of the NHS. This path seems to be explained in the combination of the competences of the specialist nurse in community and public health nursing, described in Regulation / ON n 428/2018, with PHU's attributions, provided for in its own legislation, for the majority of which this nurse is prepared, as can also be seen from the contractualization matrix, which regulates PHU's activity at HCG.

Taking into account the ongoing reforms, in the scope of primary health care in Portugal, the role of the specialist nurse in community and public health nursing may gain greater relevance, since also, in other health systems, the possibility of developing extended competences for these same health professionals is foreseen.

\section{REFERENCES}

1. Wild K, McGrath M. Public health and health promotion for nurses at a glance. UK: Wiley Blackwell; 2019.128 p.

2. Lucchese PTR. Informação para tomadores de decisão em saúde pública: políticas públicas em saúde. São Paulo: BIREME/OPAS/OMS; 2004 . 90 p.

3. Ministério da Saúde (PT). Nova ambição para a saúde pública focada em serviços locais [Internet]. 2016[cited 2019 Feb 07]. Available from: https://www.dgs.pt/documentos-e-publicacoes/nova-ambicao-para-a-saude-publica-focada-em-servicos-locais-pdf.aspx

4. Assembleia da República (PT). Proposta de Lei n 49/XIII, Lei da Saúde Pública [Internet]. 2017[cited 2019 Feb 07]. Available from: https:// www.parlamento.pt/ActividadeParlamentar/Paginas/Detalhelniciativa.aspx?BID=40898

5. Ordem dos Enfermeiros (PT). Regulamento de Competências Específicas do Enfermeiro Especialista em Enfermagem Comunitária na área de Enfermagem de Saúde Comunitária e de Saúde Pública e na área de Enfermagem de Saúde Familiar, n. ${ }^{\circ} 428 / 2018$ de 16 de julho [Internet]. 2018[cited 2019 Feb 07]. Diário da República, II Série (N. 135 de 16-07-2018) 19354-9. Available from: https://dre.pt/pesquisa/-/search/115698616/ details/normal?|=1

6. Swider SM, Levin PF, Reising V. Evidence of Public Health Nursing effectiveness: a realist review. Public Health Nurs. 2017;34(4);324-34. doi: $10.1111 /$ phn. 12320

7. George F. A saúde pública de hoje. In:V Congresso Nacional de Saúde Pública [Internet]. 2016 [cited 2019 Feb 07]. Available from: https://www.dgs.pt

8. Constituição da República Portuguesa (PT) [Internet]. 1976[cited 2019 Feb 07]. Available from: https://www.parlamento.pt/Legislacao/ Paginas/ConstituicaoRepublicaPortuguesa.aspx

9. Assembleia da República (PT). Lei de Bases da Saúde. Lei no 95/2019, de 4 de setembro [Internet]. 2019[cited 2019 Feb 07]. Available from: https://dre.pt/application/file/a/124418384

10. Governo Português (PT). Programa do XXI Governo [Internet]. 2015[cited 2019 Feb 07]. Available from: https://www.portugal.gov.pt/ ficheiros-geral/programa-do-governo-pdf.aspx, p. 93-94

11. Henriques MA, Garcia E, Bacelar M. A perspectiva da enfermagem comunitária na atenção básica em Portugal. Rev Esc Enferm USP. 2011;45(Esp.2):1786-91. doi: 10.1590/S0080-62342011000800026

12. Costa AS, Henriques A. Nursing in the governance model of health programmes. In: Leadership in Nursing: challenges for the future. European Academy of Nursing Science Summer Conference, Ghent, Belgium [Internet]. 2018[cited 2019 Feb 10]:11-2. Available from: https://bmcnurs.biomedcentral.com/articles/10.1186/s12912-018-0301-3

13. Araújo JL, Freitas RJM, Guedes MVC, Freitas MC, Monteiro ARM, Silva LMS. Brazilian Unified Health System and democracy: nursing in the context of crisis. Rev Bras Enferm. 2018;71(4):2066-71. doi: 10.1590/0034-7167-2017-0352

14. Regis CG, Batista NA. The nurse in the area of population health: concepts and competencies. Rev Bras Enferm. 2015;68(5):548-54. doi: 10.1590/0034-7167.2015680510i

15. Ministério da Saúde (PT). Termos de contratualização do SNS [Internet]. 2018[cited 2019 Feb 07]. Available from: http://www.acss.minsaude.pt/wp-content/uploads/2017/11/Termos-Referencia-Contratualizacao-SNS_2018.pdf, p. 18

16. Temido M, Dussault G. Papéis profissionais de médicos e enfermeiros em Portugal: limites normativos à mudança. Rev Port Saúde Pública. 2014;32 (1), 45-4. doi: 10.1016/j.rpsp.2013.11.002 